\section{Is there a microangiopathic antiphospholipid syndrome?}

\section{Ronald A Asherson, Sylvia S Pierangeli, Ricard Cervera}

\section{Revealing the evolution of the term APS and its commonalities with other microangiopathic disorders}

T he occurrence of small-vessel occlusions (thrombotic microangiopathy) in association with anti-phospholipid antibodies (aPL) affecting, for example, the retinal vessels, ${ }^{1}$ the nail fold, ${ }^{23}$ the skin, ${ }^{4}$ or major intrabdominal organs such as the kidney, the liver or the bowel, ${ }^{5}$ although uncommon, is well documented. These occlusions have been described in the simple or classic antiphospholipid syndrome (APS), whether or not associated with systemic lupus erythematosus (SLE), or in the primary APS, ${ }^{6}$ but they do not in any way dominate the clinical picture in these conditions. However, with the description and definition of the catastrophic APS (also known as Asherson's syndrome) in $1992^{78}$ (a new subset of the APS, often fatal, with many distinguishing characteristics separating it from the simple APS), ${ }^{9-11}$ there has been renewed interest in the thrombotic microangiopathies and their association with aPL. Although large-vessel occlusions do occur in catastrophic APS, they do not dominate the clinical picture, and their frequency is completely different from that encountered in the classic APS itself. Additionally, the catastrophic APS is frequently accompanied by a systemic inflammatory response syndrome (SIRS).

The term thrombotic microangiopathic haemolytic anaemia (TMHA) was originally introduced by Symmers ${ }^{12}$ in 1952 to describe a clinical state with localised or diffuse microvascular thrombosis in association with haemolytic anaemia and fragmented red cells referred to as schistocytes. Indeed, the great haematologist John Dacie and his colleagues ${ }^{13}$ published a seminal paper on TMHA and related the condition to vascular damage some 10 years later. TMHA encompasses a spectrum of disorders including thrombotic thrombocytopenic purpura (TTP), haemolytic-uraemic syndrome (HUS), malignant hypertension, postpartum renal failure, pre-eclampsia and catastrophic APS. Recent articles still refer to the difficulty in distinguishing among these conditions ${ }^{14}{ }^{15}$ as the overlap is so great.
With the advent of refined testing for aPL, many cases of TTP were published with this association, ${ }^{16-21}$ although Kincaid-Smith ${ }^{22}$ in 1988 had already pointed out the existence of renal thrombotic microangiopathy with lupus anticoagulant positivity. The next major advance in this field was the identification of the cleaving enzyme-a von Willebrand factor Disintegrin and Metalloproteinase ThromboSpondin protein (ADAMTS-13). Three patients with TTP and aPL have been reported so far. ${ }^{23} 24$ Espinosa et $a l^{25}$ in 2005 reviewed the association of aPL with TMHA comprehensively and found an association of TMHA with catastrophic APS rather than with classic APS. The association of HUS with aPL has also been anecdotically documented..$^{26-28}$ Simultaneous with the TTP and aPL story came the association of patients with the haemolysis, elevated liver enzymes and low platelets (HELLP) tions, ${ }^{36}$ retinal vascular occlusions ${ }^{37}$ and deep venous thrombosis (DVT) ${ }^{38}{ }^{39}$ have now been reported in patients with HELLP syndrome.

Three recent papers have speculated as to whether a continuum exists between several of these conditions (TTP, HUS, HELLP syndrome and catastrophic APS) ${ }^{40-42}$ This has been prompted by the reports of TTP and HELLP syndrome in patients in whom aPL has been demonrecent case reports of patients with HELLP syndrome and catastrophic APS. ${ }^{43} 44$ To these conditions must also be added disseminated intravascular coagulation (DIC), another situation where microvascular thromboses may be seen because of the hypercoagulability, and this may often be accompanied by a haemorrhagic state. There is usually strongly enhanced inflammatory activity, activated coagulation and impaired fibrinolysis in DIC, with a major role proposed for granulocytes. ${ }^{45} 46$ Its frequency in catastrophic APS has also been highlighted recently, ${ }^{47}$ and there have also been studies pointing out the frequency syndrome and aPL. ${ }^{29-35}$ Hepatic infarcstrated and alluded to above and also by of positive aPL demonstrated in DIC itself. ${ }^{48}$ Indeed, the index case for catastrophic APS demonstrated serological evidence of DIC. ${ }^{49}$ It should be stressed, however, that TTP, HUS, HELLP and DIC display abnormalities in the coagulation that are not usually associated with classic APS and are responsive to treatment regimens not effective in APS.

It is therefore time to address this topic objectively and to evaluate whether indeed there is a case to be made for another separate "subset" of the APSnamely, a microangiopathic APS. ${ }^{39}$ The primary APS $^{60}$ and the catastrophic APS have certainly stood the test of time as unique conditions in the APS spectrum. We now know that patients with primary APS may develop SLE with time, and also that $>80 \%$ of patients with catastrophic APS have a history of simple APS.

What is the role of the aPL (if any) in these microangiopathic conditions? Are they truly pathogenic, or are they simply "bystanders" induced by endothelial cell activation/apoptosis and exposure of phospholipid on the endothelial cell membranes of small vessels? In these conditions-for example, in TTP itself (apart from $20-30 \%$ of patients with catastrophic APS) - there are no large vascular occlusions. Hence, their relationship with the APS itself, with predominantly large-vessel occlusions, is distant, although a minority of patients with TTP demonstrate features of APS and the vast majority of patients with HELLP do not demonstrate larger vascular occlusions.

The first major player in this scenario must be the endothelial cells themselves and, in particular, those vascular endothelial cells present only on small vessels. The pathogenesis of the vascular occlusions affecting larger vessels causing DVT and strokes must then surely be different. The multifactorial pathogenesis of the APS has recently been well reviewed by Mackworth-Young. ${ }^{51}$ The second major player in this scenario is the complement cascade, and both their roles will be briefly summarised here.

\section{ANTIPHOSPHOLIPID ANTIBODIES AND ENDOTHELIAL CELLS}

Endothelial cell activation has been well demonstrated in both TTP T2-56 $^{5}$ in APS $^{57-61}$ and, recently, in HELLP syndrome. ${ }^{62}$ Studies have shown that endothelial cells express significantly higher amounts of adhesion molecules (intercellular cell adhesion molecule-1 (ICAM-1), vascular cell adhesion-1 (VCAM-1) and E-selectin) when incubated with aPL and $\beta_{2}$-glycoprotein I ( $\beta 2$-GPI) in vitro. ${ }^{63}$ Similarly, the incubation of endothelial cells with antibodies reacting with $\beta 2$-GPl has been shown to induce endothelial cell activation 
with upregulation of adhesion molecules, IL6 production and changes in prostaglandin metabolism. ${ }^{63}$ In published studies, Pierangeli et al ${ }^{64-66}$ have shown, using mouse models, that human polyclonal and monoclonal aPL activate endothelium and enhance thrombus formation in vivo. Using ICAM-1, E selectin and P-selectin knockout mice and specific monoclonal anti-VCAM-1 antibodies, the same group demonstrated that these endothelial cellactivating properties of aPL are mediated by ICAM-1, E-selectin, P-selectin and VCAM$1 .{ }^{6768}$ Some investigators have shown increased levels of soluble adhesion molecules and soluble cytokines, such as VCAM1 and P-selectin, in patients with aPL and thrombosis. ${ }^{69}{ }^{70}$ Hence, there is convincing evidence that aPL induce endothelial cell activation in vitro and in vivo.

Upregulation of tissue factor (TF) is one among the mechanisms suggested to explain the prothrombotic and proinflammatory activities of aPL. Evidence of upregulation of TF in patients with APS has also been reported by several investigators. ${ }^{71-74}$ Recently, Zhou et al ${ }^{75}$ demonstrated that IgG from patients with APS significantly increased TF function and transcription in monocytes. Some publications have also shown increased levels of soluble TF (STF) in patients with APS and thrombosis. ${ }^{70}$ Hence, there is evidence that aPL induce TF expression and procoagulant activity in vitro and in patients with APS.

Recently, the signal transduction mechanisms involved in aPL-mediated effects on endothelial cells and monocytes have been examined. Espinola et a ${ }^{68}$ first reported that aPL-induced upregulation of adhesion molecules (ie, E-selectin) in endothelial cells induce activation of nuclear factor- $\kappa \mathrm{B}(\mathrm{NF}-\kappa \mathrm{B})$ on endothelial cells in vitro. These findings were subsequently confirmed by others. ${ }^{76}$ VegaOstertag et $\mathrm{al}^{77}$ then examined the involvement of NF- $\mathrm{KB}$ and p38 mitogenactivated protein kinase (MAPK) in aPLmediated induced transcription, expression and function of TF on endothelial cells. The effects of the specific p38MAPK inhibitor SB203580 (4-(4 fluorophenyl)-2 (4methylsulfinylphenyl)-(4pyridyl) 1 imidazole) and of MG132 (carbobenzoxylleucinyl leucinylleucinal), a specific inhibitor of NF- $\mathrm{KB}$, on aPL-induced TF expression and function on endothelial cells were evaluated in vitro. The investigators showed that aPL induce significant TF transcription, function and expression on endothelial cells, pronounced increase in proinflammatory cytokines (IL6 and IL8) and phosphorylation of p38 MAPK. By using SB203580 and MG132, they demonstrated that both p38MAPK phosphorylation and NF- $\kappa \mathrm{B}$ activation are required for in vitro aPL-induced TF upregulation. ${ }^{77}$ These in vitro effects of aPL, mediated by p38MAPK and NF- $\kappa B$, were recently confirmed in monocytes by Bohgaki et al ${ }^{78}$ Similarly, López-Pedrera et $a l^{79}$ recently showed involvement of p38MAPK and ERK1/ERK2 in the activation of endothelial cells by aPL. Subsequently, Pierangeli et al showed that SB203580 significantly reduced TF function in carotid artery homogenates and in peritoneal macrophages and ex vivo expression of VCAM-1 detected by using quantum dot nanocrystal and dualphoton confocal microscopy in mice after infusion with aPL (unpublished results). These effects correlated with enhanced thrombosis and endothelial cell activation in vivo. Importantly, these findings may have important implications that may help to design new targeted treatments to treat the pro-inflammatory and prothrombotic effects of aPL in patients with APS.

It should be stressed, anyway, that endothelial perturbation and the induction of a pro-inflammatory and procoagulant phenotype is a pathogenic mechanism shared in common by several vasculopathies and vasculitic disorders. However, endothelial perturbation in APS seems to be closely linked to the ability of aPL to react with $\beta_{2}$-GPI expressed on endothelial cell membranes. This could mean that the lack of aPL in the majority of the non-APS microangiopathies makes these disorders different.

\section{ANTIPHOSPHOLIPID ANTIBODIES AND THE ACTIVATION OF THE COMPLEMENT CASCADE}

The role of complement activation by the aPL has also received a great deal of attention. Complement involvement has also been reported in some cases of TTP and HUS. Recent studies have suggested that activation of the complement cascade is necessary for aPL-mediated thrombophilia and fetal loss..$^{80-84}$ Firstly, in a study from the group of Pierangeli and Salmon and collaborators, ${ }^{80}$ it was found that inhibition of the complement cascade in vivo, using the $\mathrm{C} 3$ convertase inhibitor complement receptor l-related gene protein y (Crry)-Ig, blocks aPLinduced fetal loss and growth retardation and reverses aPL-mediated thrombosis. Furthermore, mice deficient in complement $\mathrm{C} 3$ and $\mathrm{C} 5$ (C3-/- and C5-/respectively) were resistant to thrombosis, endothelial cell activation and fetal loss induced by aPL. ${ }^{80}{ }^{84}$ Furthermore, an anti-C5 monoclonal antibody reversed thrombogenic properties of aPL in vivo, thereby confirming the involvement of $\mathrm{C} 5$ complement activation in aPL-induced thrombosis. $^{80} 84$ It has also been shown that the interaction of complement component 5a ( $\mathrm{C} 5 \mathrm{a})$ with its receptor $(\mathrm{C} 5 \mathrm{aR})$ is necessary for thrombosis of placental vasculature. ${ }^{82}$ Hence, it was concluded that complement activation is a necessary intermediary event in the pathogenesis of thrombosis and fetal loss associated with aPL in experimental APS. These findings were recently confirmed in rats by Fischetti et al, ${ }^{85}$ who showed that thrombus formation induced by antibodies to $\beta_{2}$-GPI require a priming factor such as bacterial lipopolysaccharide (LPS), and is complement dependent. The authors concluded, by using C6-deficient rats and anti-C5 miniantibody, that the terminal complement complex mediates the coagulation process. $^{85}$ Interestingly, hypocomplementaemia has been found in a significant proportion of patients with primary APS and was associated with thrombosis in one study and with livedo reticularis and thrombocytopenia in another publication. ${ }^{86-88}$

Thus, in summary, the following mechanism may be proposed for the pathogenic effects of aPL on thrombosis. Firstly, aPL bind to endothelial cells, induce their activation and a procoagulant state, as demonstrated by in vivo and in vitro studies. These include upregulation of adhesion molecules and TF expression. The aPL also induce platelet activation and interact with elements of the coagulation cascade. This activity however does not seem to be sufficient to cause thrombosis. Activation of the complement cascade by aPL may amplify these effects by stimulation of the generation of potent mediators of platelet and endothelial cell activation, including $\mathrm{C} 3 \mathrm{a}$ and $\mathrm{C} 5 \mathrm{a}$ and the C5b-9 MAC. Therefore, pathogenic aPL bind to target cells and they then activate the complement. The complement system in turn damages the endothelial cells, leading to a procoagulant state and undesirable thrombosis. We hypothesise that in patients with APS, owing to aPL deposition targeted to the endothelium, complement activation may be increased locally and may overwhelm normally adequate inhibitory mechanisms. Hence, activation of the complement may be a critical proximal effector mechanism in aPL-associated thrombosis. It is possible to speculate that inhibition of complement activation perhaps in the future should ameliorate vascular thrombosis in individuals with APS. Complement activation may be an important target that may allow us to create interventions that prevent, arrest or modify the thrombogenic and proinflammatory effects of aPL.

In conclusion, this in-depth overview raises the point whether or not there is 
any relationship between microangiopathies and APS, and reviews the pathogenic processes that may be candidate mechanisms to support such a relationship (ie, endothelial cell and complement activation), thus providing some justification for their inclusion in a separate subset of the APS-namely, a microangiopathic APS.

Ann Rheum Dis 2007;66:429-432.

doi: 10.1136/ard.2006.067033

\section{Authors' affiliations}

Ronald A Asherson, Division of Immunology, School of Pathology, University of the Witwatersrand, Johannesburg, South Africa Sylvia S Pierangeli, Division of Rheumatology, University of Texas, Galveston, Texas, USA Ricard Cervera, Department of Autoimmune Diseases, Hospital Clinic, Barcelona, Catalonia, Spain

Correspondence to: Professor Ronald A Asherson, Division of Immunology, School of Pathology, University of the Witwatersrand and the Rosebank Clinic, Johannesburg 2196, South Africa; ashron@icon.co.za

Accepted 25 January 2007

Competing interests: None declared.

\section{REFERENCES}

1 Asherson RA, Merry P, Acheson JF, Harris EN, Hughes GRV. Antiphospholipid antibodies: a risk factor for occlusive ocular vascular disease in systemic lupus erythematosus and the "primary" antiphospholipid syndrome. Ann Rheum Dis 1989;48:358-61

2 Asherson RA. Subungual splinter hemorrhages: a new sign of antiphospholipid coagulopathy? Ann Rheum Dis 1990;49:268.

3 Francès C, Piette JC, Saada V, Papo T, Wechsler B, Chosidow $\mathrm{O}$, et al. Multiple subungual splinter hemorrhages in the antiphospholipid syndrome: report of five cases and review of the literature. Lupus 1994;3:123-8.

4 Francès C, Piette JC, Asherson RA. Dermatological aspects of antiphospholipid antibody syndrome. In Sarzi Puttini P, Doria A, Girolomoni G, Kuhn A, eds. Handbook of systemic autoimmune diseases.Vol 5. Amsterdam, Elsevier 2006:103-118.

5 Von Landenberg P, Asherson RA, Piette JC. Renal, hepatic and other intraabdominal manifestations in the antiphospholipid syndrome. In: Asherson RA, Cervera R, Piette JC, Shoenfeld J, eds. The antiphospholipid syndrome 11. Amsterdam: Elsevier Science, 2002:189-204.

6 Asherson RA. A "primary" antiphospholipid syndrome? J Rheumatol 1988;15:1742-6.

7 Asherson RA. The catastrophic antiphospholipid syndrome. J Rheumatol 1992;19:508-12.

8 Piette J-C, Cervera R, Levy RA, Nasonov EL, Triplett DA, Shoenfeld $Y$, et al. The catastrophic antiphospholipid syndrome-Asherson's syndrome. Ann Med Interne (Paris) 2003;154:195-196.

9 Asherson RA, Cervera R, Piette JC, Font J, Lie JT, Burcoglu A, et al. Catastrophic antiphospholipid syndrome. Clinical and laboratory features of 50 patients. Medicine (Baltimore) 1998;77:195-207.

10 Asherson RA, Cervera R, Piette JC, Shoenfeld Y, Espinosa G, Petri MA, et al. Catastrophic antiphospholipid syndrome: clues to the pathogenesis from a series of 80 patients. Medicine (Baltimore) 2001;80:355-77.

11 Asherson RA. Multiorgan failure and antiphospholipid antibodies: the catastrophic antiphospholipid (Ashersons) syndrome. Immunobiology 2005;210:727-33.

12 Symmers W. Thrombotic microangiopathic haemolytic anemia (thrombotic microangiopathy). BMJ 1952;2:897-903.

13 Brain MC, Dacie JV, Hourihane DO. Microangiopathic hemolytic anemia. The possible role of vascular lesions in pathogenesis. Br J Haematol 1962;8:358-74.

14 Kokori SI, loannides JP, Voulgarelis M, Tzoufas AG Moutsopoulos HM. Autoimmune hemolytic anemia in patients with systemic lupus erythematosus. Am J Med 2000; 108:198-204.

15 Dold S, Singh R, Sarwar H, Menon Y, Candia LA, Espinoza R. Frequency of microangiopathic hemolytic anemia in patients with systemic lupus erythematosus exacerbation: distinction from thrombotic thrombocytopenic purpura. Prognosis and outcome. Arthritis Rheum 2005;6:982-5.

16 Jain R, Chartash E, Susin M, Furie R. Systemic lupus erythematosus complicated by thrombotic microangiopathy. Semin Arthritis Rheum $1991 ; 24: 173-82$.

17 Durand JM, Lefevre P, Kaplanski G, Soubeyrand J. Thrombotic microangiopathy and the antiphospholipid antibody syndrome. J Rheumato 1991;18:1916-18.

18 Hess DC, Sethi K, Awad E. Thrombotic thrombocytopenic purpura in systemic lupus erythematosus and antiphospholipid antibodies: effective treatment with plasma exchange and immunosuppression. J Rheumatol 1992;19:1474-8.

19 Nesher G, Hanna VE, Moore TL, Hersh M Osborn TG. Thrombotic microangiopathic anemic in systemic lupus erythematosus. Semin Arthritis Rheum 1994;24:165-72

20 Umibe T, Nawata Y, Mori N Kanai H Takabayashi K, Iwamoto T, et al. Thrombotic thrombocytopenic purpura (TTP) observed in a patient with primary antiphospholipid antibody syndrome. Ryumachi 1994;34:981-7.

21 Musa MO, Nounou R, Sahovic E, Seth P, Qadi A Aljurf $M$. Fulminant thrombotic thrombocytopenic purpura in two patients with systemic lupus erythematosus and phospholipid autoantibodies. Eur J Haematol 2000:64:433-5.

22 Kincaid-Smith P, Fairly KF, Kloss M. Lupus anticoagulant associated with renal thrombotic microangiopathy and pregnancy-related renal failure. Q J Med 1988:68:795-815.

23 Matsuda J, Sanaka T, Gohchi K, Matsui K, Uchida S, Matsumoto $M$, et al. Occurrence of thrombotic thrombocytopenic purpura in a systemic lupus patient with antiphospholipid antibodies in association with a decreased activity of von Willebrand-factor cleaving protease. Lupus 2002;11:463-4

24 Amoura Z, Costedoat-Chalimeau N, Veyradier A Wolf N, Ghillani-Dalbin P, Cacoub P, et al. Thrombotic thrombocytopenic purpura with severe ADAMTS -13 deficiency in two patients with primary antiphospholipid syndrome. Arthritis Rheum 2004:50:3260-4

25 Espinosa G, Bucciarelli S, Cervera R, Lozano M, Reverter JC, de la Red G, et al. Thrombotic microangiopathic haemolytic anaemia and antiphospholipid antibodies. Ann Rheum Dis 2004:63:730-6.

26 Kniaz D, Eisenberg GM, Elrad H, Johnson CA, Valaitis J, Bregman H. Postpartum hemolytic uremic syndrome associated with antiphospholipid antibodies. Case report and review of the literature. Am J Nephrol 1992;12:126-33.

27 Ardiles LG, Olavarria F, Elgueta M, Moya P, Mezzano S. Anticardiolipin antibodies in classic pediatric hemolytic-uremic syndrome: a possible pathogenetic role. Nephron 1998;78:278-83.

28 Meyrier A, Becquemont L, Weill P, Callard P, Rainfray $M$. Hemolytic-uremic syndrome with anticardiolipin antibodies revealing paraneoplastic systemic scleroderma. Nephron 1991;59:493-6.

29 Ornstein MH, Rand JH. An association between refractory HELLP syndrome and antiphospholipid antibodies during pregnancy: a report of 2 cases. J Rheumatol 1994:21:1360-4.

30 Ilbery $M$, Jones AR, Samson J. Lupus anticoagulant and HELLP syndrome complicated by placental abruption, hepatic, dermal and adrenal infarct. Aust N Z J Obstet Gynaecol 1995;35:215.

31 McMahon LP, Smith J. The HELLP syndrome at 16 weeks gestation: possible association with the antiphospholipid syndrome. Aust N Z J Obstet Gynaecol 1997;37:313-14

32 Alsulyman OM, Castro MA, Zuckerman E, McGehee W, Goodwin TM. Preeclampsia and liver infarction in early pregnancy associated with the antiphospholipid syndrome. Obstet Gynaecol 1996:88:644-6.

33 Nagayama K, Izumi N, Miyasaka Y, Saito K, Ono K, Noguchi O, et al. Hemolysis, elevated liver enzymes, and low platelets syndrome associated with primary antiphospholipid antibody syndrome. Intern Med 1997:36:6661-6.

34 Roberts G, Gordon MM, Porter D, Jardine AG Gibson TW. Acute renal failure complicating HELLP syndrome, SLE and antiphospholipid syndrome; successful outcome using plasma exchange therapy. Lupus 2003;12:251-7.

35 Le Thi Thuong D, Tieulie N, Costedoat N Andreu MR, Wechsler B, Vauthier-Brouzes, et al. The HELLP syndrome in the antiphospholipid syndrome: retrospective study of 16 cases in 15 women. Ann Rheum Dis 2005;64:273-8.

36 Pauzner R, Dulitzky M, Carp H, Mayan H, Kenett R, Farfel Z, et al. Hepatic infarctions during pregnancy are associated with antiphospholipid syndrome and in addition with complete or incomplete HELLP syndrome. J Thromb Haemost 2003;1:1758-63.

37 Gonzalvo FJ, Abecia F, Pinilla I, Izaguirre LB, Olivan JM, Honrubia FM. Central retinal vein occlusion and HELLP syndrome. Acta Ophthalmol Scand 2000;5:596-8

38 Paternoster DM, Rodi J, Santarossa C, Vanin M, Simioni P, Girolami A. Acute pancreatitis and deep vein thrombosis associated with HELLP syndrome. Minerva Ginecol 1999;51:31-3.

39 Spargo C, Asherson RA. Bilateral deep vein thrombosis, HELLP syndrome and antiphospholipid antibodies. (In Press).

40 Merrill JT, Asherson RA. Catastrophic antiphospholipid syndrome. Nat Clin Pract Rheumatol 2006;2:81-9.

41 Asherson RA, Cervera R, Merrill JT. Thrombotic microangiopathic antiphospholipid syndromes: continuum of conditions? Future Rheumatol 2006;1:1-9.

42 Asherson RA. New subsets of the antiphospholipid syndrome in 2006: "PreAPS" (probable APS) and microangiopathic antiphospholipid syndromes ("MAPS"). Autoimmunity Reviews 2006;6:76-80.

43 Sinha J, Chowdry I, Sedan S, Barland P. Bone marrow necrosis and refractory HELLP syndrome in a patient with catastrophic antiphospholipid antibody syndrome. J Rheumatol 2002;29:195-7.

44 Koenig M, Roy M, Baccot S, Cuilleron M, De Filippis J-P, Cathebrasl P. Thrombotic microangiopathy with liver, gut and bone infarction (catastrophic antiphospholipid syndrome) associated with HELLP syndrome. Clin Rheumato 2005;2:166-8

45 Levi M. Current understanding of disseminated intravascular coagulation. $\mathrm{Br} J$ Haematol 2004; 124:567-76.

46 Slofstra SH, Spek A, ten Cate H. Disseminated intravascular coagulation. Haematology 2003:4:295-302

47 Asherson RA, Espinoza G, Cervera R, Gomez Puerta JA, Musuruana J, Bucciarelli S, et al. Disseminated intravascular coagulation in catastrophic antiphospholipid syndrome: clinical and hematological characteristics of 23 patients. Ann Rheum Dis 2005;64:943-6.

48 Karmochkine M, Mazoyer E, Marcelli A, Boffa A Piette JC. High prevalence of antiphospholipid antibodies in disseminated intravascular coagulation. Thromb Hemost 1996;75:971.

49 Bird AG, Lendrum R, Asherson RA, Hughes GRV. Disseminated intravascular coagulation, antiphospholipid antibodies and ischemic necrosis of extremities. Ann Rheum Dis 1987;46:251-5.

50 Asherson RA, Khamashta MA, Ordi-Ros J, Derksen RH, Machin SJ, Barquinero J, et al. The "primary" antiphospholipid syndrome: major clinical and serological features. Medicine (Baltimore) 1989;68:366-74. 
51 Mackworth-Young C. Antiphospholipid syndrome: multiple mechanisms. Clin Exp Immunol 2004; 136:393-401.

52 Burns ER, Zucker-Franklin D. Pathologic effects of plasma from patients with thrombotic thrombocytopenic purpura on platelets and cultured vascular endothelial cells. Blood 1982;60:1030-7.

53 Prapotnik S, Blank M, Levy Y. Antiendothelial cell antibodies from patients with thrombotic thrombocytopenic purpura specifically activate small vessel endothelial cells. Int Immunol 2001; 13:203-10.

54 Romani DW, Fijnheer R, Brinkman HJ, Kersting S, Hene RJ, van Mourik JA. Endothelial cell activation in thrombotic thrombocytopenic purpura (TTP). Br J Haematol 2003;123:522-7.

55 Mitra D, Jaffe EA, Weksler B, Haijar KA, Soderland C, Laurence J. Thrombotic thrombocytopenic purpura and sporadic hemolyticuremic syndrome plasmas induce apoptosis in restricted lineages of human microvascular endothelial cells. Blood 1997;89:1224-34

56 Dang CT, Magid MS, Weksler B, Chadburn A, Laurence J. Enhanced endothelial cell apoptosis in splenic tissues of patients with thrombotic thrombocytopenic purpura. Blood 1999;93:1264-70.

57 Simatov R, La Sala JM, Lo SK, Gharavi AE, Sammaritano LR, Salmon J, et al. Activation of cultured endothelial cells by antiphospholipid antibodies. J Clin Invest 1995;96:221 1-19.

58 Meroni PL, Raschi E, Camera, et al. Endothelial activation by aPL: a potential pathogenetic mechanism for the clinical manifestations of the syndrome. J Autoimmun 2000;15:237-40.

59 Raschi E, Testoni C, Borghi MO, Fineschi S, Meroni PL. Endothelium activation in the antiphospholipid syndrome. Biomed Pharmacother 2003;7:282-6.

60 Pierangeli SS, Chen PP, Gonzales EB. Antiphospholipid antibodies and the antiphospholipid syndrome: an update on treatment and pathogenic mechanisms. Curr Opin Hematol 2006; 13:366-75

61 Pierangeli SS. In search for a receptor for antiphospholipid antibodies on target cells. J Thromb Haemost 2006;4:1678-9.

62 Hulstein JJ, van Runnard Heimel PJ, Franx A, et al. Acute activation of the endothelium results in increased levels of active Von Willebrand factor in HELLP syndrome. J Thromb Haemost 2006;4:2569.

63 Del Papa N, Guidali L, Sala A, et al. Endothelial cell target for antiphospholipid antibodies. Human polyclonal and monoclonal anti- $\beta_{2}$ glycoprotein and induce endothelial cell activation. Arthritis Rheum 1997;40:551-61.

64 Pierangeli S, Colden-Stanfield M, Liu X, et al. Antiphospholipid antibodies from antiphospholipid syndrome patients activate endothelial cells in vitro and in vivo. Circulation 1999;99:1997-2000.
65 Gharavi AE, Pierangeli SS, Colden-Stanfield M, et al. GDKV-induced antiphospholipid antibodies enhance thrombosis and activate endothelial cells in vivo and in vitro. J Immunol 1999;163:2922-7.

66 Pierangeli SS, Liu X, Espinola R, et al. Functional analyses of patient-derived $\lg G$ monoclonal anticardiolipin antibodies using in vivo thrombosis and in vivo microcirculation models. Thromb Haemost 2000;84:388-95.

67 Pierangeli SS, Espinola RG, Liu X, Harris EN Thrombogenic effects of antiphospholipid antibodies are mediated by intercellular cell adhesion molecule-1, vascular cell adhesion molecule-1, and P-selectin. Circ Res 2001;88:245-50.

68 Espinola RG, Liu X, Colden-Stanfield M, Hall J, Harris EN, Pierangeli J, et al. E-selectin mediated pathogenic effects of antiphospholipid antibodies. $J$ Thromb Haemost 2002;1:843-8.

69 Kaplanski G, Cacoub P, Farnarier C, Marin V, Gregoire R, Gatel A, et al. Increased soluble vascular cell adhesion molecule 1 concentrations in patients with primary or systemic lupus erythematosus-related antiphospholipid syndrome: correlations with the severity of thrombosis. Arthritis Rheum 2000;43:55-64.

70 Forastiero RR, Martinuzzo ME, De Larranaga G. Circulating levels of tissue factor and proinflammatory cytokines in patients with primary antiphospholipid syndrome or leprous related antiphospholipid antibodies. Lupus 2005; 14:129-36.

71 Cuadrado MJ, Lopez-Pedrera C, Khamashta MA, Camps MT, Tinahones F, Torres A, et al. Thrombosis in primary antiphospholipid syndrome: a pivotal role for monocyte tissue factor expression. Arthritis Rheum 1997:40:834-41.

72 Amengual O, Atsumi T, Khamashta MA, Hughes GRV. The role of the tissue factor pathway in the hypercoagulable state in patients with the antiphospholipid syndrome. Thromb Haemost 1998;79:276-81.

73 Dobado-Barrios M, Lopez-Perrara C, Velasco F, Aguirre MA, Turres A, Cuadrado MJ, et al. Increased levels of TF mRNA in mononuclear blood cells of patients with primary antiphospholipid syndrome. Thromb Haemost 1999;82:1578-82.

74 Martini F, Farsi A, Gori AM, Boddi M, Fedi S, Domeneghetti MP, et al. Antiphospholipid antibodies (aPL) increase the potential monocyte procoagulant activity in patients with systemic lupus erythematosus. Lupus 1996;5:206-11.

75 Zhou H, Woldberg AS, Roubey RA.

Characterization of monocyte tissue factor activity induced by $\lg G$ antiphospholipid antibodies and inhibition by dilazep. Blood 2004;104:2353-8.

76 Dunoyer-Geindre S, de Moerloose P, Galve-de Rochemonteix B, Reber G, Kruithof EK. NF- $\kappa$ B is an essential intermediate in the activation of endothelial cells by anti- $\beta_{2}$ glycoprotein antibodies. Thromb Haemost 2002;88:851-7.
77 Vega-Ostertag M, Casper K, Swerlick R, Ferrara D, Harris EN, Pierangeli SS, et al. Involvement of p38 MAPK in the up-regulation of tissue factor on endothelial cells by antiphospholipid antibodies. Arthritis Rheum 2005;52:1545-54.

78 Bohgaki M, Atsumi T, Yamashita Y, Yasuda S Sakai $Y$, Furusaki $A$, et al. The p38 mitogenactivated protein kinase (MAPK) pathway mediates induction of the tissue factor gene in monocytes stimulated with human monoclonal anti$\beta_{2}$ glycoprotein I antibodies. Int Immuno 2004; 16:1632-41.

79 López-Pedrera C, Buendia P, Cuadrado MJ Siendones $E$, Aguirre MA, Barbarroja $N$, et al Antiphospholipid antibodies from patients with the antiphospholipid syndrome induce monocyte tissue factor expression through the simultaneous activation of NF-kappaB/Rel proteins via the p38 mitogen-activated protein kinase pathway, and of the MEK-1/ERK pathway. Arthritis Rheum 2006;54:301-1153.

80 Holers VM, Girardi G, Mo L, Guthridge JM Molina $\mathrm{H}$, Pierangeli SS, et al. C3 activation is required for anti-phospholipid antibody-induced fetal loss. J Exp Med 2002; 195:21 1-20.

81 Salmon JE, Girardi G, Holers VM. Complement activation as a mediator of antiphospholipid antibody induced pregnancy loss and thrombosis. Ann Rheum Dis 2002;61:46-50.

82 Girardi G, Berman J, Redecha P, Spruce L, Thurman JM, Kraus D, et al. Complement C5a receptors and neutrophils mediate fetal injury in the antiphophospholipid syndrome. J Clin Invest 2003;112:1644-54.

83 Girardi G, Redecha P, Salmon J. Heparin prevents antiphospholipid antibody-induced fetal loss by inhibiting complement activation. Nat Med 2004; 10:1222

84 Pierangeli SS, Girardi G, Vega-Ostertag ME, Liu X Espinola RG, Salmon J, et al. Requirement of activation of complement $\mathrm{C} 3$ and $\mathrm{C} 5$ for antiphospholipid antibody-mediated thrombophilia. Arthritis Rheum 2005;52:2120-4.

85 Fischetti F, Durigutto P, Pellis V, Debeus A, Macov P, Bulla $P$, et al. Thrombus formation induced by antibodies to $\beta_{2}$-glycoprotein I is complementdependent and requires a priming factor. Blood 2005; 106:2340-6

86 Carbone J, Oerra M, Rodriguez-Mahou M, Rodriguez-Peres C, Sanchez Ramon S, Seoane E, et al. Immunological abnormalities in primary APS evolving into SLE: 6 years follow-up in women with repeated pregnancy loss. Lupus 1999;8:274-8.

87 Munakata Y, Saito T, Matsuda K, et al. Detection of complement-fixing antiphospholipid antibodies in association with thrombosis. Thromb Haemost 2000;83:728-31

88 Davis WD, Brey RL, Seino J, Shibata S, Sasaki T. Antiphospholipid antibodies and complement activation in patients with cerebral ischemia. Clin Exp Immunol 1992; 10:455-60. 